\title{
Quantitative strategy planning matrix in supporting sustainability of pearl millet (Pennisetum glaucum) farming
}

\author{
Ikawati Karim ${ }^{1 *}$; Edy Fitriawan Syahadat ${ }^{2}$; Rahman Basri ${ }^{3}$ \\ 1),3) Agribusiness Department, Universitas Sulawesi Barat, Indonesia \\ 2) Faculty of Economics, Universitas Sulawesi Barat, Indonesia \\ *To whom correspondence should be addressed.E-mail: ikawati@ unsulbar.ac.id
}

\begin{abstract}
Pearl millet is not only a potential source of income for farmers but can also support the availability of alternative local food in West Sulawesi. As a potential local food, pearl millet contains good nutrition such us anti-oxidant, bioactive compound and fiber. This research is aim to analyze the internal and external factors, IE matrix and then Quantitative Strategy Planning Matrix (QSPM) in order to figure out the priority strategies of pearl millet (Pennisetum glaucum) farming. This research was conducted in West Sulawesi by investigating pearl millet farmers in the production center. The strategy that could be applied is how to support an aggressive growth-oriented strategy. The priority strategies to be implemented are 1) procurement of farming equipment to increase production and productivity, 2) maximizing land potential through efficient farming input, 3) supporting farmers to keep trying to grow pearl millet in an effort to produce alternative food, 4) the use of environmentally friendly farming equipment and input technologies to support sustainability, 5) training to the pearl millet farmers on processing and diversification of pearl millet into industrial products, 6) building adequate infrastructure to facilitate distribution and marketing, 7) plotting pearl millet as a potential superior local food in West Sulawesi, 8) facilitating to access to capital by activating rural-based microfinance institutions, 9) increasing the capacity of farmers and village stakeholders through institutional strengthening, counseling and training and 10) introducing pearl millet to the market and consumers as a local food that is rich in fiber and high antioxidants.
\end{abstract}

Keywords: Internal and external factors, Local food, Pearl millet, Quantitative strategy planning matrix

JEL Classifications: C65, O13, Q10

\section{INTRODUCTION}

Pearl millet ranked sixth as the most important grain and consumed one-third on the world's population (Marlin, 2009; Karim, Makmur \& Bahmid, 2019). Approximately two-thirds people in Southern Asia is suffering in severe food insecurity in the world (FAO, 2017; Silungwe et al, 2019). Because of the climate change, the loss of total harvest belong to farmer is still prevalent (Hoffman et al, 2018). Pearl millet (Pennisetum glaucum) is a food commodity that has the potential to be developed in an effort to strengthen food security as a source of carbohydrates instead of rice. Pearl millet is originated from the Sahel Region of Africa (United US Department of Agriculture, 2014; Sheahan, 2014) and also this plant can grow in various regions in Indonesia, including in 


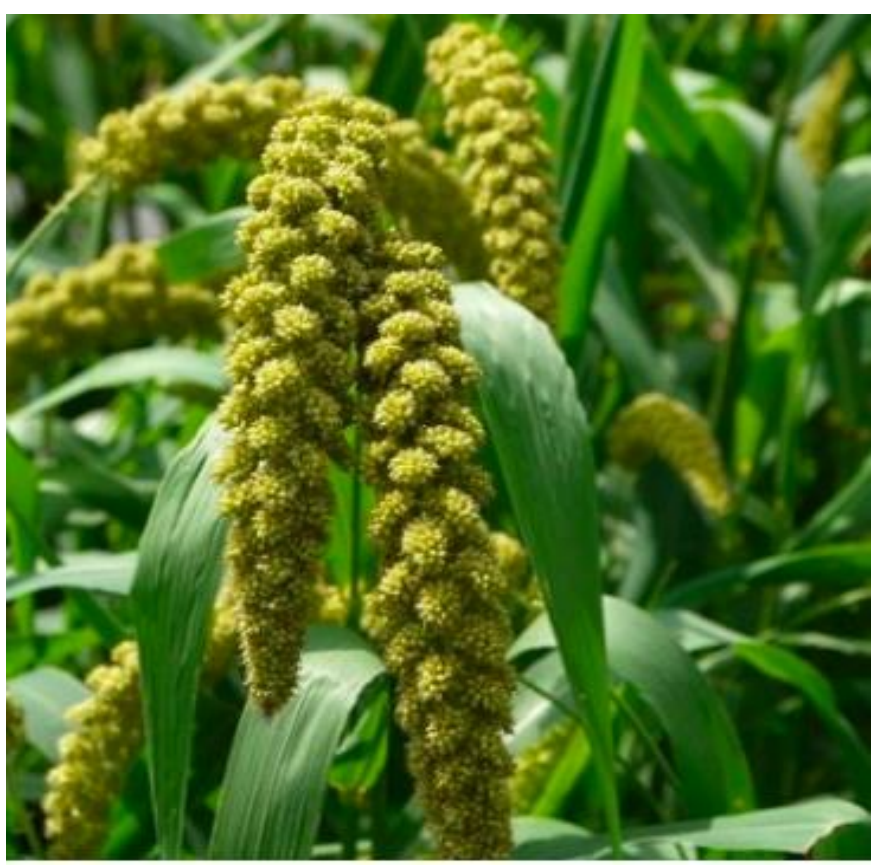

West Sulawesi. Pearl millet has the advantage over other carbohydrate plants that can grow on almost all types of soil including dry and less fertile soils, easy to cultivate, short plant life and its various uses (Suherman, Zairin \& Awaluddin, 2005).

Pearl Millet is a high energy cereal that contains carbohydrate, protein, and also fat. It is a food rich in vitamins $\mathrm{B}$ and $\mathrm{A}$, high in calcium, iron and zinc, it also contains potassium, phosphorus, magnesium, copper and manganese. The grain of pearl millet has a higher energy, higher protein content than other cereals

Figure 1. Pearl Millet (www.floradanfauna.com)

and foods. Any traditional food in West Sulawesi is produced from pearl millet, such as porridges and traditional cakes. Pearl millet could also processed as foods and beverages such as couscous, flat breads, doughs, gruel, non-alcoholic beverages and beers (Taylor, 2016).

West Sulawesi is one of the potential areas for the development of pearl millet and even it is recorded in the Ministry of Agriculture as local food precisely in Polewali Mandar Regency. Any problem faced to develop of sustainability of pearl millet in Indonesia such as low technology in farming system, limited access to the capital, fluctuation of price and production, limited access to the market. So that, it is important to figure out the most appropriate strategies to increase the sustainability of pearl millet farming both internal and external factors. Another way to improve sustainability, crop enhancement strategies should be prioritized for adoption (Mumo, Yu \& Fang, 2018).

\section{METHODS}

This research was conducted in Polewali Mandar. The location was defined by purposive as one of the pearl millet centers in West Sulawesi, Indonesia by interviewing three - group, consist of 49 pearl millet farmers who intensively cultivate of it. Data represented with descriptive quantitative by using Internal Factor Evaluation (IFE) and External Factor Evaluation (EFE), IE matrix and then Quantitative Strategy Planning Matrix (QSPM) in order to arrange the appropriate strategies that reliable to be implemented. QSPM is a method for comparing some feasible actions. There is no strategy limit that can be evaluated or the number of strategies that can be examined at the same time in using QSPM (Rangkuti, 2009).

\section{RESULTS AND DISCUSSION}

\section{Internal Factors Evaluations (IFE)}

Internal factors in supporting the development of pearl millet farming are carried out by identifying internal factors evaluation based on indicators of strengths and weaknesses (Setiady, 2014). This analysis aims to assess and evaluate internal strategic 
factors that influence the success of the pearl millet farming recommended in its development strategy. Internal factors are described in the following IFE matrix table.

Table 1. Internal factors evaluation of pearl millet farming

\begin{tabular}{|c|c|c|c|c|}
\hline No & Internal Factors & weight & rating & score \\
\hline A. & Strengths & & & \\
\hline 1 & Potentially local food & 0.1082 & 4 & 0.432 \\
\hline 2 & Income alternative & 0.1122 & 3 & 0.340 \\
\hline 3 & Rich in nutrition & 0.1070 & 4 & 0.423 \\
\hline 4 & Resistant to climate change & 0.1034 & 1 & 0.103 \\
\hline 5 & Short production period & 0.0839 & 2 & 0.168 \\
\hline \multirow[t]{2}{*}{6} & Land availability & 0.0875 & 4 & 0.350 \\
\hline & Total Strengths & 0.6025 & & 1.000 \\
\hline B. & Weakness & & & \\
\hline 1 & Farming equipment & 0.0835 & 2 & 0.167 \\
\hline 2 & Production cost & 0.0838 & 3 & 0.251 \\
\hline 3 & Human resource & 0.0768 & 1 & 0.076 \\
\hline 4 & Capital & 0,0796 & 3 & 0.239 \\
\hline \multirow[t]{4}{*}{5} & Post-harvest processing & 0.0735 & 3 & 0.220 \\
\hline & Total Weaknesses & 0.3139 & & $\mathbf{0 , 6 0 9}$ \\
\hline & Total & 1.0000 & & 1.609 \\
\hline & Strengths - Weak & $\mathbf{S}-\mathbf{W}$ & & \\
\hline
\end{tabular}

Source: Primary data after analyzed, 2019

Based on the analysis of the IFE matrix in Table 1 shows that the factors that influence the development of pearl millet farming in terms of strength have a cumulative value of 0.6025 higher than the cumulative value of the weaknesses of 0.3139 . This situation indicates that the development of pearl millet farming in the strength factors are higher than the weakness factors that will inhibit it. Strength and weakness of the organization or company is about how to identify the competitiveness, ability to compete, and in-depth strategy to win the competition among competitors (Rantelino, 2015) and how to manage the potential resources to guarantee sustainable of pearl millet farming.

The internal factors evaluation for developing pearl millet farming in West Sulawesi based on the strengths are potentially local food, income alternative for the local farmers. It is also rich in nutrition such as antioxidant, fibers, fat and higher protein content (Taylor, 2016). Millet is one of the foods which resistant to climate change. In Africa, pearl millet (Pennisetum glaucum) is the most dries land food crop (Rowland 1993; Mustafa and Arshad, 2014). The other strengths are short production period, it's around 3-4 months (BPTP Balitbangtan,2016) which is can grow on poor soil elemental or subtropical soil with $\mathrm{pH}$ 4-8 (Grubben \& Partohardjono, 1996) and also land availability, in this case, most of farmers have enough land to produce pearl millet even most of farmers in West Sulawesi only produce pearl millet, once in a year. According to the Grubben \& Partohardjono (1996) millet was cultivated in the end of rainy season.

Although pearl millet has many strengths in order to develop, but some of weaknesses were identified such us farming equipment to produce pearl millet. It's still traditional and low input technology either in on-farm system or post-harvest processing. Technology in agriculture is important to increase farmers' yields (Zulkarnaen, 2016).

\section{External Factors Evaluation (EFE)}

External factors evaluation aims to identify external strategic factors that influence in order to develop of the pearl millet farming. External factors are described in the following EFE matrix table: 
Table 2. External factors evaluation of pearl millet farming

\begin{tabular}{|c|c|c|c|c|}
\hline No & External Factors & weight & rating & score \\
\hline A. & \multicolumn{4}{|l|}{ Opportunities } \\
\hline 1 & Access to the market & 0.1780 & 4 & 0.712 \\
\hline 2 & Assistance of farming equipment & 0.1168 & 2 & 0.232 \\
\hline 3 & Developing infrastructure and communication & 0.1489 & 3 & 0.447 \\
\hline \multirow[t]{2}{*}{4} & Supporting price policy & 0.1652 & 2 & 0.330 \\
\hline & Total of opportunities & 0.6090 & & 1.691 \\
\hline B. & \multicolumn{4}{|l|}{ Threats } \\
\hline 1 & Competition among food products & 0.1389 & 1 & 0.138 \\
\hline 2 & Competition among other commodities & 0.1295 & 2 & 0.258 \\
\hline \multirow[t]{4}{*}{3} & Innovation and diversification other products & 0.1224 & 3 & 0.366 \\
\hline & Total of threats & 0.3909 & & $\mathbf{0 . 7 6 2}$ \\
\hline & Total & 1.0000 & & 2.453 \\
\hline & \multicolumn{4}{|c|}{ Opportunities - Threats $=\mathrm{O}-\mathrm{T}=\mathrm{Y}=\mathbf{1 . 6 9 1}$} \\
\hline
\end{tabular}

Source: Primary data after analyzed, 2019

Based on the analysis of the EFE matrix in Table 2 above, it shows that the cumulative value of the opportunities (opportunity) of 0.609 is higher than the cumulative value of the threat (treats) of 0.390 , this condition shows that the opportunity factor for the development of pearl millet farming is higher than threat factors that will inhibit it. External evaluation is the external audit of performance to develop a finite of list of opportunities that can provide benefits and threats to be avoid (Setiady, 2014). Either IFE or EFE, this analysis bargains to find out the most appropriate strategy applied to the company and it's also possible to applied in agricultural business and farming.

The opportunities to develop of pearl millet farming are access to the market which is so far, pearl millet production purpose for consumption needed than for distribution to the market. The problem is found that in supporting production process, farmers still use the traditional equipment so that assistance of farming equipment are also needed by the pearl millet farmers. Actually, for distribution activities, it's urgent to develop infrastructure and communication. Another case is about supporting price policy. In this case, weak farmers will lead to asymmetric price information and the powerlessness of marketing management in buying and selling transactions is still a problem (Kementerian Pertanian, 2017).

Otherwise, the threats are also identified such us competition among food products and other commodities. Then, innovation and diversification other agricultural products. With so many competitors, both rice and non-rice products, the added value of pearl millet needs to be focused. For sure, production through innovation and technology needs to be done consistently and sustainably in increasing food quality (Kementerian Pertanian, 2017) and how plotting pearl millet as a market oriented products.

\section{Internal and external matrix}

After the internal and external factors evaluation, the next is the Internal and External (IE) Matrix. The internal and external matrix is used to position the various divisions within a company against nine cell strategies. It is also specifically designed to assist the effort of multidivisional companies in formulating strategy (David, 2010; Fitri, 2014). Each cell size strategy describes the condition of the pearl millet farming. In positioning IE matrix based on two-key dimensions which the total IFE score on the $\mathrm{X}$ axis (horizontal) and the EFE weight score on the Y axis (vertical) (Budiyono, 2017).

From the results of the total score of strength and weakness factors in the IFE matrix is 1,609 and the total score of the opportunity and threat factors in the EFE matrix is 
2,453 . The pearl millet farming strategy position is in cell the strategy 6 which is divestment, in which productivity of pearl millet is low and possibility loss because of any problem such us farming equipment, capital, human resources and post-harvest handling. In addition, access to the market, infrastructure and government policy are also the main problem for developing of millet in West Sulawesi. The strategy to solve these conditions are to raise capital for the improvement of pearl millet farming so that it needs to sell productive assets such as land, buildings and other assets to obtain fresh funds. Another source of capital is actually from the micro-finance which is gotten from banking sector or another finance supporting. Capital is needed to fund pearl millet farming in supporting on-farm activities and post-harvest handling where the pearl millet farming needs additional resources to improve existing conditions, as illustrated in the following matrix. This condition described that to sustain of the pearl millet farming faced a serious problem base on the matrix position, it is a combination of weak and low cell based on the matrix position.

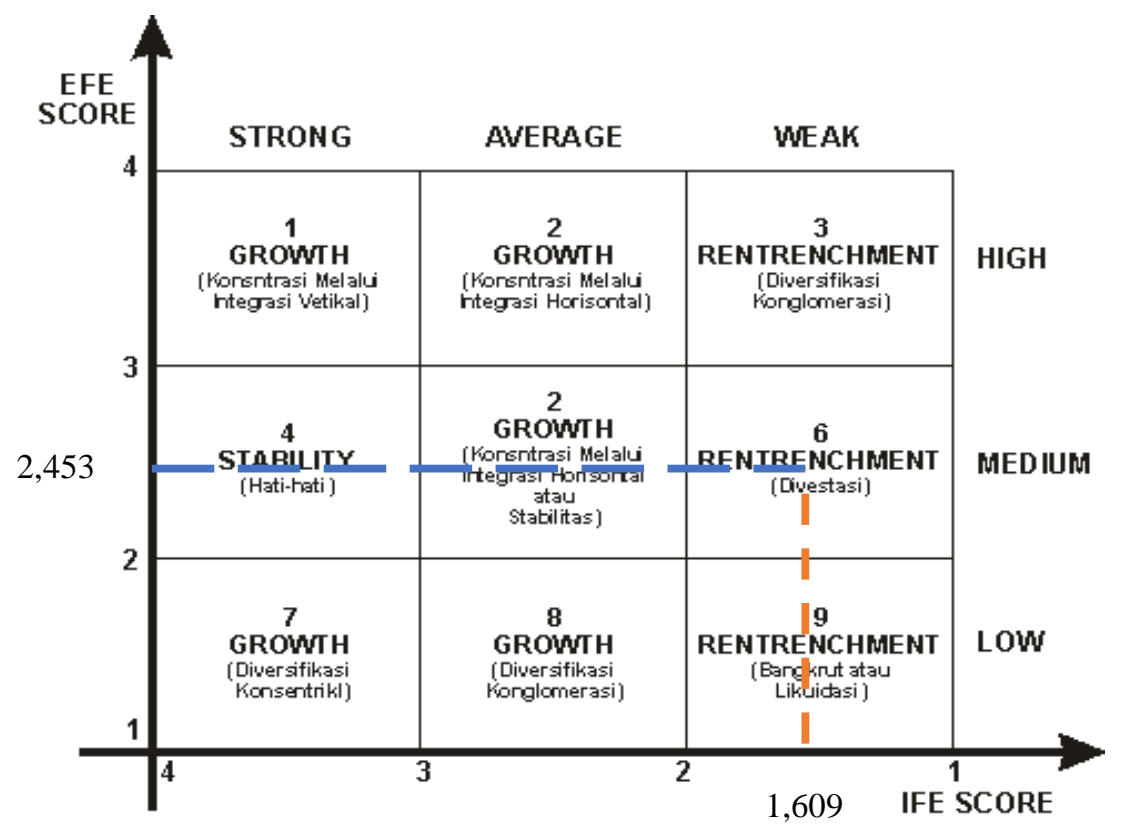

Figure 2. Internal and External Matrix

In this case, pearl millet farmers have not been able to do a farming business well so some strategies that are considered important in the divestment for the development of pearl millet farming in Polewali Mandar are:

- Avoid savings, to restore the existing conditions

- Farming needs more resources than currently available

- pearl millet farmers are responsible for the overall poor business performance

- Farmers do not engage their farming as they should

- Farming requires a substantial source of capital than is available, obtained through the sale of productive assets owned by farmers.

\section{Quantitative strategy planning matrix}

Quantitative Strategy Planning Matrix (QSPM) is an analysis tool used to determine priority strategies to be implemented. After the SWOT analysis is formulated strategies based on key factors in the IFE and the EFE matrix, then further determine the priority of the strategy to be implemented in increasing production in pearl millet farming both in quantity and quality. Selection of alternative strategies within QSPM, using 
Attractive Score (AS) and the Total of Attractive Score (TAS) based on the weight score from the IFE and EFE Evaluation where AS value using the Likert scale; 1) not acceptable, 2) probably acceptable, 3) possibly acceptable, 4) acceptable, 5) not relevant or by value 1) Not attractive, 2) rather interesting, 3) quite interesting, 4) very interesting (Alamanda, Anggadwita, Raynaldi, Novani \& Kijima, 2019).

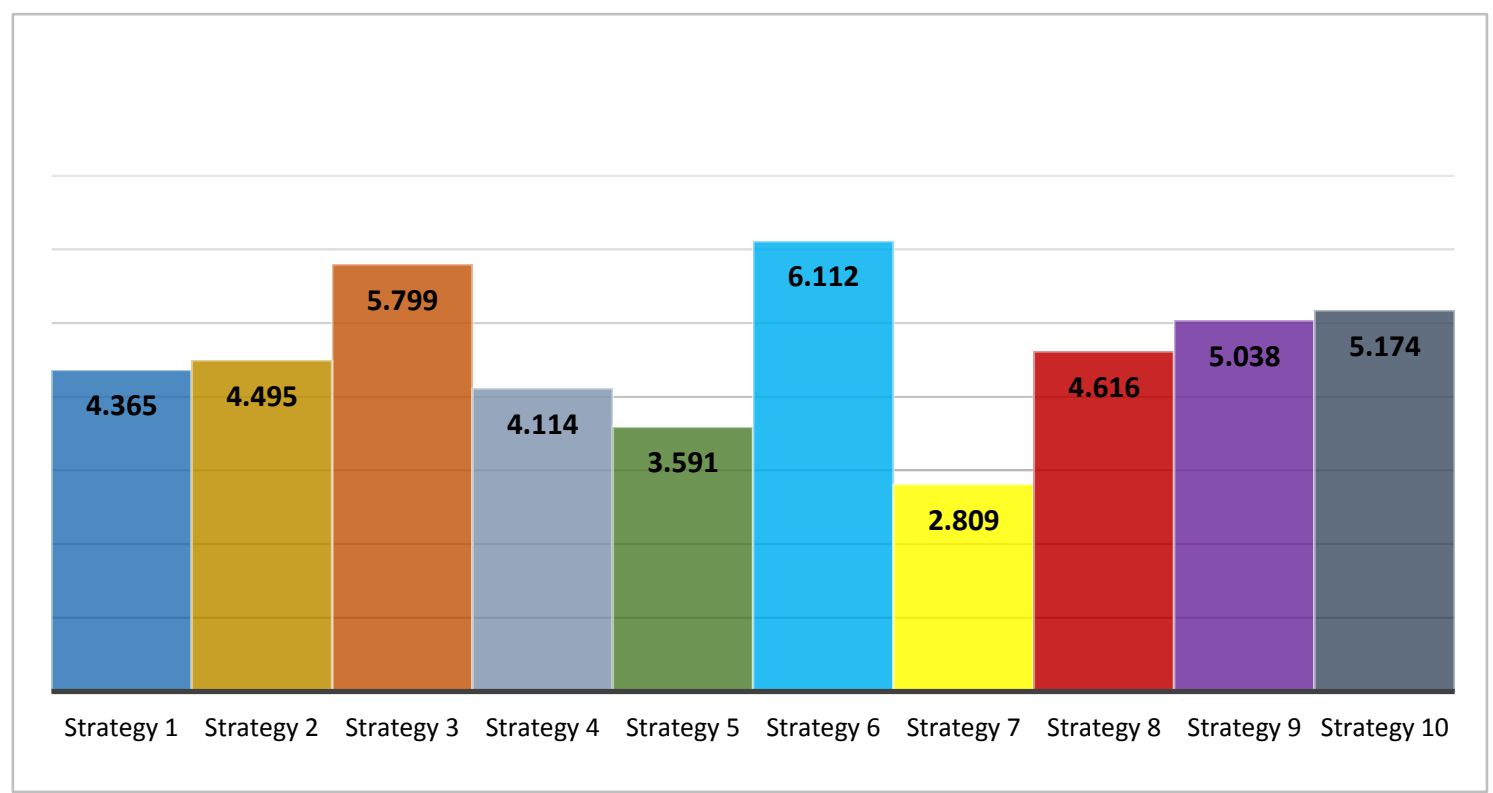

Figure 3. Total Attractive Score (TAS) of Quantitative Strategy Planning Matrix (QSPM)

Based on figure 3, it appears that the order of the most priority strategies based on the Total Attractive Score (TAS) from highest to lowest are as follows:

- Strategy 6 has a total attractive score (TAS) of 6.112, the procurement of farming equipment to facilitate farmers in increasing production and productivity.

- Strategy 3 with a total attractive score (TAS) of 5.799, maximizing the potential of land through efficient farming input.

- Strategy 10 has a total attractive score (TAS) of 5.174, supporting farmers to keep trying to grow pearl millet in an effort to produce alternative food.

- Strategy 9 has a total attractive score (TAS) of 5.038, the use of environmentally friendly farming technologies and inputs to support sustainability.

- Strategy 8 has a total attractive score (TAS) of 4.616; training on processing and diversification of pearl millet into industrial products.

- Strategy 2 with a total attractive score (TAS) of 4.495; building adequate infrastructure to facilitate distribution and marketing.

- Strategy 1 with a total attractive score (TAS) of 5,365; plotting pearl millet as a potential superior food in West Sulawesi.

- Strategy 4 with a total attractive score (TAS) of 4.114 , accessing to capital by activating rural-based microfinance institutions.

- Strategy 5 with a total attractive score (TAS) of 3.591, increasing the capacity of farmers and village stakeholders through institutional strengthening, counseling and training.

- Strategy 7 has a total attractive score (TAS) of 2.809, introducing pearl millet to the market and consumers as a local food that is rich in fiber and high antioxidants.

These priority strategies are important to maintain and recommend to the government as one of the support systems who will bring pearl millet as the superior local food in West Sulawesi which is not only for food security (Karim, Makmur \& Bahmid, 
2019) but also for industrial needed. This period time, pearl millet has expanded its cultivation in several major countries in East Asia. From China, then this plant spread to another Asian Country such us Indonesia, Japan, India, Africa, Egypt, Greece, Italy and America. Some countries are used as human diet, some are as birdseed. actually, pearl millet is an alternative for food consume and other potential industrial products in which the production extremely limited. Total production in the world reached 28,38 million tons (FAO, 1991).

\section{CONCLUSION AND RECOMMENDATION}

\section{Conclusion}

To sum up, the pearl millet farming strategy based on internal dan factor matrix is the strategy 6 (six) which is divestment strategy. Then, the most priority strategies for the pearl millet farming are the procurement of farming equipment to facilitate farmers in increasing production and productivity, maximizing the potential of land through efficient farming input, supporting farmers to keep trying to grow pearl millet in an effort to produce alternative food, the use of environmentally friendly farming technologies and inputs to support sustainability, training on processing and diversification of pearl millet into industrial products, building adequate infrastructure to facilitate distribution and marketing, plotting pearl millet as a potential superior food in West Sulawesi, accessing to capital by activating rural-based microfinance institutions, increasing the capacity of farmers and village stakeholders through institutional strengthening, counseling and training, and introducing pearl millet to the market and consumers as a local food that is rich in fiber and high in antioxidants.

\section{Recommendation}

The development of local food products such as pearl millet is encouraged and been the focus of government's and private sectors attention in increasing both at the farmers and regional income. Moreover, it can be encouraged as a local food excellence of West Sulawesi which is needed for food security and industry.

\section{ACKNOWLEDGEMENT}

The authors would like to acknowledge to Direktorat Riset dan Pengembangan Manusia (DRPM), Ministry of Research, Technology and Higher Education of Indonesia (KEMENRISTEKDIKTI). We also would like to acknowledge to LPPM Universitas Sulawesi Barat.

\section{REFERENCES}

Alamanda, D.T., Anggadwita, G., Raynaldi, M., Novani,S. \& Kijima, K. (2019). Designing Strategies Using IFE,EFE,IE and QSPM Analysis: Digital Village Case. The Asian Journal of Technology Management, 12(1), (2019) 48-59.

BPTP Balitbangtan Sulawesi Barat. (2016). Potensi dan Teknologi Budidaya Jewawut (Setaria italica) di Sulawesi Barat. Badan Litbang-Kementerian Pertanian Republik Indonesia.

Budiyono, G.L. (2017). Mapping and Selecting Competitive Strategy, European Research Studies Journal, XX(A4), 696 - 706

David, F.R. (2010). Strategic Management Concept. Book 1, Issue 12, Salemba, Jakarta.

FAO, IFAD, UNICEF, WFD, WHO (2017). The State of Food Security and Nutrition in the World 2017. Building Climate Resilience for Food Security and Nutrition. FAO: ROME, Italy.

FAO. (1991). Millet Production Systems. Available at: http://www.fao.org/3/W1808E/ w1808e0c.htm 
Fitri, F. (2014). Reformulation of Business Development Strategy at KJKS Muamalah Berkah Sejahtera. Sharia Economics Study Program, Sunan Ampel State Islamic University, Surabaya.

Grubben, G.J.H \& Partohardjono,S. (1996). Cereal: Plant Resources of South-East Asia No.10. PROSEA, Bogor.

Hoffman, M.P., Haakana, M., Asseng, S., Hohn,J., Palosuo T., Ruiz Ramos, M., Fronzek, S, Ewert, F., Gaiser, T. \& Kassie, B. (2018). How Does Inter-Annual Variability of Attainable Yield Affect The Magnitude of Yield Gaps for Wheat and Maize? An Analysis at Ten Sites. Agricultural System, 159, 199-208.

Karim, I, Makmur \& Bahmid, N.A. (2019). Pearl Millet (Pennisetum glaucum) Farming for Food Security: Gross output, net farm income and B/C ratio. IOP Conference Series: Earth and Environmental Science.

Kementerian Pertanian. (2017). Kebijakan Pembangunan Pertanian: Upaya Peningkatan Produksi Komoditas Pertanian Strategis. Available at: www.pertanian.go.id.

Marlin, S. (2009). Sumber Pangan Tanaman Minor. Available at: http://daengnawan.blogspot.com/2009/07/sumber-pangan-tanaman-minor.html

Mumo, L., Yu, J. \& Fang, K. (2018). Assessing Impact of Seasonal Climate Variability on Maize Yield in Kenya. International Journal Plant Production, 12(4), 297-307.

Mustapha, A.B \& Arshad, A.M. (2014). Millet the Promising Crop of The Climate Change. Journal of Biology, Agriculture and Healthcare, 4(15), 153-156

Rangkuti, F. (2009). Analisis SWOT. Teknik Membedah Kaukus Bisnis. PT. Gramedia Pustaka Utama, Jakarta.

Rantelino, H. (2015). Analisis SWOT, Analisis Jitu bagi Para Pelaku Bisnis. Available at: https://www.kompasiana.com/heriyanto_rantelino/ 54f346e17455137e2b6c6f20/analisis-swot-analisis-jitu-bagi-para-pelakubisniscompasiana.com.

Setiady, A. (2014). Analysis of IFE (Internal Factors Evaluation) and IFE (Internal Factors Evaluation) Matrix IFE Key Internal Factor Weight Rating Weighted Score Strength Financial. Available at: https://www.academia.edu/8460210/ ANALYSIS_OF_IFE_Internal_Factors_Evaluation_and_EFE_External_Factors_ Evaluation_Matrix_IFE_Key_Internal_Factor_Weight_Rating_Weighted_Score_ Strength_Financial

Sheahan, C.M. (2014). Plant Guide for Pearl Millet (Pennisetum glaucum). USDANatural Resources Conservation Services, Cape May Plant Material Center, Cape May.

Silungwe, F.R., Graef, F., Kmura, S.D.B., Tumbo, S.D., Kahimba, F.C \& Lana, M.A. (2019). The Management Strategies of Pearl Millet Farmers to Cope with Seasonal Rainfall Variability in a Semi-Arid Agroclimate. Agronomy, 9, 400.

Suherman, O., Zairin, M., dan Awaluddin. (2005). Keberadaan dan Pemanfaatan Plasma Nutfah Jewawut di Kawasan Lahan Kering Pulau Lombok. Laporan Tahunan pusat Penelitian Serealia Balai Penelitian Tanaman Serealia Maros, Sulawesi Selatan.

Taylor, J.R.N. (2016). Millet;Pearl. Reference Modul in Food Science. Available at: https://www.sciencedirect.com/science/article/pii/B9780081005965000111

United State Department of Agriculture. (2014). Pearl Millet (Pennisetum glaucum) (L.) $R$. Br. Natural Resources Conservation Service. United, State.

Zulkarnaen, F.J. (2016). Dampak Teknologi dalam Pertanian. Available at: https://www.wattpad.com/4264905-pola-kegiatan-perekonomian-dampakteknologi-dalam 